\title{
Experiência e negatividade em Gadamer
}

\author{
Gadamer on Experience and Negativity
}

\author{
Felipe Ribeiro* \\ feliperibeiro1848@gmail.com \\ (Universidade de São Paulo, São Paulo, Brasil)
}

\begin{abstract}
Resumo: 0 artigo busca analisar a noção de experiência negativa utilizada por Gadamer para descrever a experiência hermenêutica. Ao fazer isso, temos como objetivo refutar duas leituras problemáticas que são feitas a respeito da experiência hermenêutica: por um lado, que esta não tem a forma positiva e otimista que uma leitura simplista de Verdade $e$ método poderia sugerir; por outro, que o intérprete também pode estabelecer uma quebra de identificação com a tradição, o que permitirá por sua vez entender como a relação hermenêutica com a tradição não implica cega submissão a esta, sendo antes mediada por uma distância.
\end{abstract}

Palavras chaves: Gadamer; hermenêutica; negatividade; experiência; tradição.

\begin{abstract}
The article aims to analyze Gadamer's notion of hermeneutic experience as a negative experience. Such exposition will allow us to criticize two common readings: on the one hand, that hermeneutic experience doesn't take the form of a positive and optimistic experience, as many would like to assume; on the other hand, that by means of such negativity the interpreter establishes a break of identification with tradition, so that the relation to tradition doesn't imply blind submission to it, but a relation mediated by distance.
\end{abstract}

Keywords: Gadamer; Hermeneutics; Negativity; Experience; Tradition.

DOI: http://dx.doi.org/10.11606/issn.2318-9800.v25i1p69-88

De modo geral, acho que devemos ler apenas os livros que nos cortam e nos ferroam. Se o livro que estivermos lendo não nos despertar como um golpe na cabeça, para que perder tempo lendo-o, afinal de contas? [...] Precisamos, na verdade, de livros que nos toquem como um doloroso infortúnio, como a morte de alguém que amamos mais do que a nós mesmos, que nos façam sentir como se tivéssemos sido expulsos do convívio para as florestas, distantes de qualquer presença humana, como um suicídio. Um livro tem de ser o machado que rompe o oceano congelado que habita dentro de nós.

Franz Kafka

\footnotetext{
* O presente artigo reproduz um capítulo da minha dissertação de mestrado a respeito do debate entre Habermas e Gadamer, defendida em 2017 sob orientação do Prof. Dr. Fernando Costa Mattos, na UFABC. A pesquisa contou com apoio da FAPESP (processo $n^{\circ}$ 2017/19934-4).
} 


\section{Introdução}

À primeira vista, numa leitura simplista, algumas fórmulas que descrevem a hermenêutica gadameriana parecem denotar um acento positivo na experiência circunscrita pela interpretação. Exemplos disso encontramos na maneira como o próprio Gadamer acentua repetitivamente com o epíteto de “produtividade" o caráter positivo de ideias que descrevem a experiência hermenêutica: a distância temporal enquanto "possibilidade positiva e produtiva do compreender" (Gadamer, 2015, p. 393 [302]), ${ }^{1}$ o "sentido ontológico positivo" do círculo hermenêutico (idem, p. 355 [271]), a intenção de "tornar positivas" as “considerações negativas” da Aufklärung sobre o conceito de preconceito (idem, p. 361 [276]). Conceito que, por meio de uma "reabilitação da tradição e da autoridade", ganhará, nas mãos de Gadamer, um "valor positivo" (idem, p. 368 [282]). Enfim, todos esses elementos parecem destacar o "milagre" que ocorre na compreensão, como se na relação hermenêutica com a tradição houvesse algo de celebrativo - lembremos aliás que o próprio Gadamer usa o conceito de "festa" para descrever a experiência hermenêutica da obra de arte (idem, p. 180 [128]). Ora, que tudo isso dê azo à impressão de que Verdade e método celebra a positividade da experiência de pertença à tradição, é algo cuja suspeita o próprio Gadamer simula no "Prefácio à segunda edição". Como perguntado por ele: “[a] universalidade da compreensão não significa uma unilateralidade quanto ao conteúdo, já que carece de um princípio crítico diante da tradição e presta homenagem, por assim dizer, a um otimismo universal?" (idem, p. 25; 1990b, p. 447). Fica, com isso, a impressão de que a experiência hermenêutica opera uma transmissão tranquila e imperturbada da tradição, que corresponde a uma recepção acrítica da parte de um leitor passivo que celebra ingenuamente sua relação com o passado, tornando-se um só com ele.

Gadamer, no entanto, não deixou de fornecer pistas para não nos deixarmos enganar por essa primeira aparência. Como dirá ele em "A continuidade da história e o instante da existência", texto de 1965, que consta entre os "complementos" de Verdade e método: a continuidade que a reflexão hermenêutica logra mediar através do descontínuo

não é a certeza tranquila, que habita no extremo do historicismo perfeito, de que, em todo lugar onde algo perece, o acontecer pode da mesma forma se articular como um novo começo [...] Não se trata de uma certeza inquestionável, mas ao

\footnotetext{
1 As citações se referem à edição brasileira de Verdade e método / e II. Entre colchetes, será inserida a paginação da edição alemã das obras completas de Gadamer, cuja edição pode ser verificada em nossas referências bibliográficas. Exceção apenas para as citações referentes ao "Prefácio à segunda edição", que na edição brasileira está em Verdade e método I, enquanto na versão alemã está no fim de Verdade e método II. Neste caso, indicaremos não por meio de colchetes, mas fazendo referência à data da edição alemã de Verdade e método Il. Alguns trechos terão a tradução modificada sem aviso prévio.
} 
contrário, de uma tarefa imposta a toda consciência da experiência humana. Ela se executa na transmissão [Überlieferung] e na tradição [Tradition]. Mas nela não há nada da segurança tranquilizante própria daquilo que se realiza por si mesmo. A transmissão e a tradição não gozam da inocência da vida orgânica. Elas podem ser também combatidas com paixão revolucionária onde aparecerem sem vida e rígidas. A transmissão e a tradição afirmam seu verdadeiro sentido não ao se agarrarem ao que foi herdado, mas quando se apresentam como parceiros experientes e contínuos no diálogo que nós somos. E na medida em que nos respondem e dessa forma nos colocam novas questões, elas comprovam sua própria realidade efetiva e sua contínua vivacidade (Gadamer, 2011, p. 172 [143-4]).

A reflexão hermenêutica, embora produtiva, não conta com uma transmissão orgânica e imperturbada, que passaria adiante uma mensagem como uma certeza confortável. Trata-se, antes, de um confronto com um interlocutor mais experiente que lança na insegurança as convicções do intérprete. Uma experiência que recoloca as perguntas a este, lançando suas ideias na interrogação, sem o abono da resposta definitiva, o que transforma a interpretação numa tarefa a ser cumprida. Ora, essa intranquilidade do contato com a tradição, que depende da disposição ativa do intérprete para desdobrar a tensão com ela, aponta para o lado eminentemente negativo da experiência hermenêutica. $\mathrm{E}$, de fato, é na seção de Verdade e método intitulada "O conceito de experiência e a essência da experiência hermenêutica" (Gadamer, 2015, p. 453 [352]), onde Gadamer discute o conceito de experiência que interessa à hermenêutica, que ele o apresentará como um "processo essencialmente negativo" (idem, p. 461 [359]). Em lugar de certeza e recepção tranquila, temos negação e interrogação.

No que se segue, analisaremos essa dimensão da experiência hermenêutica, visando afastar a concepção segundo a qual Gadamer celebra otimisticamente a experiência de pertencimento à tradição. Faremos isso, num primeiro momento, reconstituindo o conceito de experiência negativa, em sua oposição ao conceito positivo de experiência, para, em seguida, extrair as implicações disso para a relação hermenêutica com a tradição. Trata-se de mostrar que, em oposição à experiência positiva, que estabelece uma identificação ingênua e não reflexiva com o objeto - isto é, não mediada por quebras, erros e frustrações -, Gadamer lança mão de um conceito de experiência no qual o intérprete vivencia a não coincidência entre suas projeções e a tradição legada. Isso significa que, mesmo onde a interpretação termina numa identificação, ela é sempre mediada por um trabalho reflexivo e crítico, ou seja, negativo. Não se trata mais de recepção passiva, que anula qualquer distância entre intérprete e tradição, mas de uma tensão com a tradição que interessa desdobrar. Desse ângulo, veremos que a acusação de que Gadamer simplesmente celebra o otimismo da tradição deveria estar muito mais ao lado do conceito positivo de experiência, ao qual ele opõe seu próprio conceito de experiência. 


\section{Experiência, negatividade e historicidade}

Reportando-nos à seção referida sobre o conceito hermenêutico de experiência, vamos então analisar seu aspecto negativo. Antes, vale ter em mente o principal objetivo que norteia esse passo da argumentação de Gadamer. Como se sabe, um dos principais objetivos da $2^{\mathrm{a}}$ parte de Verdade e método é a "Elevação da historicidade da compreensão a um princípio hermenêutico". Para Gadamer, "[a] verdadeira experiência é experiência da própria historicidade" (idem, p. 467 [363]), de forma que "[a] consciência hermeneuticamente qualificada incluirá assim a consciência histórica" (idem, p. 395 [304]). 0 conceito de experiência que interessa é um que faz jus à historicidade da compreensão - que é justamente a função da experiência negativa. Isso permite a Gadamer proceder sua definição de forma negativa, isto é, a partir do conceito oposto de experiência aistórica, que é a experiência positiva. Seguindo Gadamer, começaremos pela descrição do conceito desta última, para passar ao seu oposto.

Para este conceito positivo, a experiência se refere às projeções bem sucedidas efetuadas pelo intérprete, que permitem a fixação de universalizações que se acumulam em direção a abstrações mais abrangentes, até o nível dos axiomas. Trata-se de um procedimento indutivo, que está justamente no centro da tentativa de generalizar um método científico para as ciências do espírito. ${ }^{2}$ Segundo Gadamer, tal noção pode ser reportada a Bacon, para quem, por exemplo, um experimento seria "um hábil direcionamento do nosso espírito", pelo qual este ascende "gradual e continuamente até os axiomas, pelo caminho de um procedimento de exclusão (idem, p. 456 [354]). O caminho, aqui, é da confirmação, em que a experiência comprova e legitima nossas expectativas, em vez de problematizá-las.

Para Gadamer, entretanto, nesse processo teleológico de aprendizado, as experiências negativas, isto é, aquelas que não se confirmaram no objeto, são descartadas e esquecidas. É nesse sentido, segue Gadamer, que "Bacon fala da tendência do espírito humano de reter na memória unicamente o positivo e esquecer as instantiae negativae. A fé nos oráculos, por exemplo, nutre-se dessa capacidade humana de esquecer, que retém na memória as predições acertadas e não leva em conta as equivocadas" (idem, p. 457 [355]). Note-se que, ao associar experiências positivas e esquecimento, Gadamer aponta para a importância da memória das experiências frustradas e inclui um teor temporal em torno do conceito de experiência. Para ele, na medida em que a experiência positiva conduz a um esquecimento de seu percurso negativo, ela produz uma negação de sua própria historicidade, como que esquecendo-se do percurso de sua história: “Uma experiência só é válida na medida

2 Ver a gênese histórica que Gadamer (2015, p. 37 [9] ss.) faz de como o método indutivo é introduzido para tentar conferir cientificidade às ciências do espírito, especialmente sob autoria de J. S. Mill. 
em que se confirma [...]. Mas isto significa que, por sua própria essência, a experiência suspende em si mesma sua própria história e a extingue [...]. Nesse sentido, na ciência não pode restar espaço para a historicidade da experiência” (idem, p. 454 [352-3]). Se a experiência positiva, organizada segundo induções bem-sucedidas, conduz a um esquecimento do negativo e, com isso, de sua historicidade, então é possível dizer que a recuperação da negatividade da experiência, como será realizada por Gadamer, busca fazer jus à sua historicidade. Nesta linha, a verdadeira experiência hermenêutica é aquela que mantém um contato próximo com a lembrança de seus erros e antecipações que não deram certo. No que diz respeito ao problema de uma relação cega com a tradição, Gadamer está interessado justamente nas experiências que geram uma ruptura de identificação do objeto, e não uma adesão sem mediações a ele. Quer dizer, nosso autor quer descrever a experiência hermenêutica como sendo mediada por tentativas frustradas de identificação, isto é, como uma experiência mediada por erros, que abre o intérprete à historicidade de suas preconcepções. Historicidade que é diferente da do objeto interpretado. Isso não só salvaguarda uma certa não identidade do intérprete com o interpretado, mas implica também que, sempre que a identificação é alcançada, ela é mediada por um percurso de verificação crítica das antecipações.

É possível reconhecer que essa ênfase na autenticidade da experiência negativa se apresenta como resposta a um dilema imposto pelo princípio central que Gadamer introduz para fazer jus à historicidade da compreensão: o princípio da história dos efeitos. Como se sabe, seu objetivo é precisamente "mostrar a realidade da história na própria compreensão” (idem, p. 396 [305]). Ainda que opere como princípio metodológico recorrente na interpretação de textos apartados historicamente do leitor, Gadamer inova ao reconhecer na história dos efeitos uma determinação ontológica da compreensão: “Compreender é essencialmente um processo de história dos efeitos” (idem, ibidem). Quer dizer, não se trata mais de pensar a compreensão da história como uma etapa separada do próprio curso histórico, e sim defender que a compreensão é ela mesma um efeito ou ação [Wirkung] da história, de maneira que a interpretação da tradição se converte num momento do ser da própria tradição, funcionando como um desdobramento dela. A interpretação é ela mesma históricoefeitual [wirkungsgeschichtelich]. Queira ou não, o intérprete já está sempre determinado pela tradição que busca compreender, o que implica um componente inconsciente no ser determinado pela tradição: “a ação [Wirkung] dessa história dos efeitos [Wirkungsgeschichte] está operando em toda compreensão, estejamos ou não conscientes disso" (idem, p. 398 [306]). Daí que a ideia de consciência da história dos efeitos [wirkungsgeschichteliches Bewußtsein] comporte a ambiguidade de se referir tanto à consciência inconscientemente "ativada e determinada no curso da história", quanto ao ato de tomar consciência “do próprio ser ativado e determinado" (idem, 
p. 398; 1990b, p. 444). Ora, o que interessa a Gadamer é que a interpretação não se deixe mais guiar cegamente por "preconceitos não percebidos" que "nos tornam surdos para a coisa de que nos fala a tradição" (idem, p. 359, [274]), mas tome uma posição ativa diante de sua própria historicidade, "a fim de que o próprio texto possa apresentar-se em sua alteridade, podendo assim confrontar sua verdade com as opiniões prévias pessoais" (idem, p. 358 [274]). O objetivo da consciência histórica hermenêutica implica assim a necessidade de incutir a negatividade necessária contra nossas próprias concepções, para "não dissimular" a "tensão entre texto e presente", mas para “desenvolvê-la conscientemente” (idem, p. 405 [311-2]). Daí que a historicidade da compreensão terá que aparecer na forma de uma experiência negativa, isto é, na forma de um confronto entre nossas antecipações e o objeto da experiência, abrindo o caminho da historicidade, em vez de uma mera positivação de nossas expectativas, que excluiria a historicidade de seu fazer. 0 intérprete tem de desdobrar sua tensão com o texto interpretado, e não se entregar a ele de maneira irrefletida.

Mas eis o dilema. Se a determinação histórica da compreensão opera de maneira inconsciente, como tomar consciência daquilo que, por definição, escapa à consciência? O intérprete não dispõe livremente de suas opiniões prévias, derivadas de seu momento no curso da história dos efeitos. Como então "escapar ao circuito fechado das próprias opiniões prévias" (idem, p. 357 [272])? Para responder, Gadamer apoia-se na produtividade da distância temporal, que funciona como um fator de "filtração [Filterung]", na medida em que cristaliza um hábito linguístico temporalmente diferente do intérprete. Como diz ele: o que o permite a testar a historicidade de seus próprios usos de linguagem (cf. 2011, p. 80 [63-4]). Isso conduz à experiência do choque [Anstoß] que permite ao intérprete tomar consciência de seus preconceitos: "o que nos faz parar e perceber uma possível diferença do uso da linguagem é só a experiência do choque que um texto nos causa - seja porque ele não faz nenhum sentido, seja porque seu sentido não concorda com nossas expectativas" (2015, p. 357 [272]). É a "experiência do erro" (Gadamer, 1996, p. 79) ou de um atopón, um "não lugar", "aquilo que não se encaixa no esquematismo de nossa expectativa de compreensão e que por isso nos deixa desconcertados, estupefatos" (Gadamer, 2011, p. 218 [185]). Como diz Palmer, "a experiência é, antes de tudo, experiência de uma 'não-dade' [not-ness] - algo não é como havíamos pensado" (1969, p. 195). Assim, o intérprete projeta no texto expectativas de sentido cultivadas num determinado tempo, mas, ao não vê-las confirmada, em função do sentido histórico diferente assumido pelas palavras, precisa reconhecer a historicidade própria dos usos linguísticos, os seus e os alheios. É este choque que permite que o intérprete tome consciência de hábitos linguísticos inconscientes, que operavam de maneira não problemática, já que apresenta uma alternativa a eles. Há um movimento 
de autoestranhamento, podemos dizer, pelo qual é possível ter experiência da particularidade dos próprios hábitos até então tidos como naturais. Note-se que o choque é eminentemente negativo: em função da historicidade de nossos hábitos linguísticos, nossas antecipações não se confirmam na coisa e, com isso, se abre um caminho para retomarmos nossos hábitos, reconhecendo sua especificidade.

Se voltarmos agora, notaremos que é isso que a experiência positiva impede. Ao se concentrar apenas nas universalizações que dão certo, ela valoriza exclusivamente as projeções iniciais que se confirmam no outro, não deixando reconhecer a historicidade própria da interpretação e, com ela, a diferença existente entre o intérprete e aquilo que ele interpreta, uma certa não identidade. Na experiência positiva, não há um momento de estranhamento, de não confirmação, que abre o caminho para reflexão. Seu movimento acaba sendo aquele em que "não se distingue o que é o próprio e o que é do outro” (Gadamer, 2015, p. 397 [306]), de forma que o intérprete se vê "dominado acriticamente pelos conceitos prévios e preconceitos de seu próprio tempo” (idem, p. 513 [400]). Ora, esta é justamente a atitude do historicismo, que renuncia "a uma reflexão desse tipo, esquecendo sua historicidade" (idem, p. 396 [304]). Note-se, para adiantar nosso argumento, que essa indiferenciação ou identificação positiva com o outro, que não raro ouvimos atribuírem ao conceito de Gadamer de experiência da tradição, é justamente o que ele está buscando combater - por meio da negação, o intérprete sabe guardar a distância histórica que o separa de seu objeto. Recuperando a historicidade e a negatividade da experiência, Gadamer quer ao mesmo tempo dispor de um conceito de experiência hermenêutica que implique uma relação mediada com o objeto, que se efetue por quebras de identificação, por frustrações, revisões críticas etc. Daí que podemos retomar uma citação em que Gadamer afirma que experiência hermenêutica é uma tarefa. Nela não há a recepção passiva e acrítica, mas um confronto em certo sentido perturbador. Gadamer retoma uma forma de Ésquilo, segundo a qual o aprendizado é um sofrimento (idem, p. 466 [362]).

Seja como for, este é o pano de fundo a partir do qual Gadamer descreve o processo negativo pelo qual um intérprete toma consciência histórica de sua própria compreensão, abrindo-o a novas experiências. Tal processo, segundo ele,

é essencialmente negativo. Ele não pode ser descrito simplesmente como a formação, sem rupturas, de universalidades típicas. Essa formação se dá, antes, pelo fato de as falsas universalizações serem constantemente refutadas pela experiência; as coisas tidas por típicas são destipificadas. Na linguagem, isso se dá ao falarmos de experiência num duplo sentido; de um lado, as experiências que correspondem às nossas expectativas e as confirmam; de outro, a experiência que se "faz". Esta, a verdadeira experiência, é sempre negativa. Quando fazemos uma experiência com um objeto, significa que até então não havíamos visto corretamente as coisas e que só agora nos damos conta de como realmente são. Assim, a negatividade da experiência possui um sentido marcadamente produtivo. Não é simplesmente um engano que é 
visto e corrigido, mas representa a aquisição de um saber mais amplo. Desse modo, o objeto com o qual se faz uma experiência não pode ser um objeto escolhido ao acaso. Antes, deve proporcionar-nos um saber melhor, não somente sobre si mesmo como também sobre aquilo que antes se acreditava saber, isto é, sobre o universal. A negação, em virtude da qual a experiência chega a esse resultado, é uma negação determinada. A essa forma de experiência, damos o nome de dialética (idem, p. 461$2[359])$.

Ao dizer que a verdadeira experiência é aquela que se faz, Gadamer se refere à experiência no sentido biográfico: não uma experiência que confirma nossas antecipações, mas aquela que apresenta algo novo diante delas. Algo que não tem lugar em nossos esquemas prévios, que os nega e, ao mesmo tempo, permite o aprendizado de algo que antes não sabíamos. ${ }^{3}$ Daí que seja o conceito enfático de experiência, enquanto Erfahrung, que implica descoberta, em oposição à vivência [Erlebnis] de dados imediatos. Desse modo, comenta Araújo, o homem deixa de ser "a identidade absoluta do positivo" (2008, p. 125), para se tornar aquilo que Omar Bilen chama de um “contínuo processo de integração e negação” (2000, p. 60).

Esse aspecto da experiência coincide, aliás, com a ideia de formação [Bildung], já que esta significa sobretudo a maturidade para poder lidar com coisas desligadas da particularidade imediata do intérprete, um "desligamento [detachement] de si próprio", nos termos de Di Cesare (2013, p. 39), ou, nas palavras de Gadamer, "para a distância com relação a si mesmo, levando a ultrapassar a si mesmo e alcançar a universalidade", e que por isso mesmo permite certo alheamento em questões mais universais cujo efeito retroativo é a possibilidade de voltar e ter uma visão mais apurada da própria particularidade de partida, isto é, vê-la "como os outros veem" (2015, p. 53 [22-3]). Por isso que, inversamente, “[q]uem se entrega à particularidade" - e podemos dizer, não está aberto ao efeito negativo da experiência da alteridade - "é inculto [ungebildet]", isto é, "não consegue abstrair de si e ter em vista um sentido universal, pelo qual paute sua particularidade com medida e postura" (idem, p. 47-8 [18]). Ora, a interpretação vem a ser então esse modo de ampliar a perspectiva do intérprete a partir de pontos de vista mais abrangentes que oferecem um choque ou negação da opinião inicial, mas inaugurando um processo de formação. ${ }^{4} \mathrm{O}$ aprendizado tem sempre um aspecto negativo, marcado por erros

\footnotetext{
3 É possível que esteja aqui a origem secreta da descrição de Habermas, em Conhecimento e interesse, da experiência fenomenológica em Hegel como experiência biográfica: "Como mostra o âmbito prototípico da experiência biográfica, as experiências que ensinam são as negativas. A reversão da consciência significa: a dissolução das identificações, a ruptura de fixações, a destruição de projeções. 0 fracasso do estado de consciência sobrepujado se traduz ao mesmo tempo em uma atitude nova e refletida, na qual se toma consciência, sem distorções, da situação tal como ela é. Este é o caminho da negação determinada" (2014, p. 46-7). Não é difícil reconhecer um espírito gadameriano nessa maneira de descrever a experiência fenomenológica.

4 Embora a referência para tal ideia seja Hegel, não é difícil reconhecer aqui também o princípio do pensamento ampliado, tal como definido por Kant na Crítica da faculdade de julgar: "o que [...] caracteriza um homem com um modo de pensar ampliado quando ele é capaz de ir além das
} 
produtivos.

Como estamos vendo, a negatividade da experiência não resulta num vazio. Daí a importância do recurso de Gadamer a Hegel, para quem a verdadeira experiência é pensada nos termos de uma negação determinada. De fato, Gadamer, preocupado em dar conta da historicidade da experiência e, assim, de seu aspecto negativo, elogia em Hegel o fato de que, com ele, "o momento da historicidade obtém seu direito" (idem, p. 462 [359]). Segundo nosso autor, isso ocorre na medida em que Hegel apresenta a experiência na forma de uma "estrutura de uma inversão da consciência e é por isso que se constitui num movimento dialético" (idem, p. 463 [360]). Neste caso, quando se faz uma experiência, "o que antes era inesperado passa a ser previsto [...] Somente um novo fato inesperado pode proporcionar uma nova experiência a quem já possui experiências. Desse modo, a consciência que experimentou inverteu-se, ou seja, voltou-se sobre si mesma” (idem p. 462 [359]). A referência explícita, aqui, é a "Introdução" da Fenomenologia do Espírito, onde Hegel apresenta a experiência como uma espécie de comparação que a consciência realiza sobre seu estado atual e o saber que ela tem sobre esse mesmo estado, uma experiência negativa que ela realiza sobre si mesma, de maneira que ela percebe a não verdade interna de suas ideias, experimentando-as como falsas. A consciência é aí confrontada com a não-verdade que ela comporta em si mesma, o que é vivido com desespero. Ocorre que, em Hegel - e o mesmo valerá para Gadamer -, essa experiência é produtiva: o reconhecimento da falsa consciência não significa cair numa negação absoluta, pois, pelo movimento negativo, a consciência já produziu uma nova figura de si mesma, mais elevada ou mais experiente, uma vez que enriquecida pelos estágios anteriores. Assim, diria Hegel, se

o resultado [da negação] for apreendido tal como ele é em verdade, isto é, como negação determinada, então imediatamente uma nova forma nasce, e na negação é efetuada a transição pela qual tem lugar o processo espontâneo que se realiza através da série completa das figuras da consciência (Hegel, 2003, p. 76).

A seu modo, Gadamer emprega a mesma ideia para descrever a experiência da interpretação. Esta, ao entrar em contato com a tradição, prossegue na forma da negação de falsas antecipações. Trata-se de positivações que são destipificadas, como visto, o que gera o choque. No entanto, como isso desencadeia o contato com uma perspectiva mais ampliada, legada pela tradição, o intérprete entra num processo de formação. Daí que a negação hermenêutica seja negação determinada, pois de uma concepção prévia negada nasce um novo momento enquanto resultado. Aqui, portanto, podemos reconhecer que o verdadeiro resultado da experiência

condições subjetivas privadas, entre as quais tantos outros estão como que presos, e refletir sobre o seu próprio juízo de um ponto de vista universal (que ele só pode estabelecer colocando-se no ponto de vista dos outros)" (Kant, 2016, p. 192-3). 
acaba sendo um princípio cuja importância Gadamer não cansa de reiterar, a saber, a abertura ao outro. Essa abertura não exige, porém, uma "neutralidade", pois depende da posição em jogo dos preconceitos do intérprete, que se abre ao diferente justamente na medida em que o confronta com suas concepções prévias: “O que importa é dar-se conta dos próprios pressupostos para que o próprio texto possa se apresentar em sua alteridade, podendo assim confrontar sua verdade com as opiniões prévias pessoais" (Gadamer, 2015, p. 358 [274]). Num certo sentido, o reconhecimento do diferente depende sempre de uma autocontenção, para que o outro se apresente sem que nossas ideias prévias borrem sua especificidade. Daí que Davey possa falar em uma "abertura disciplinada à alteridade" (2006, p. 4), que o próprio Gadamer nomeia de “vigilância da consciência da história dos efeitos" (2015, p. 405 [312]).

É por essa razão também que Gadamer se afasta de Hegel. O que incomoda a Gadamer é sobretudo o saber absoluto que encerra o percurso fenomenológico de formação da consciência. Na Fenomenologia do espírito, tal estágio produz uma identidade do espírito consigo mesmo: o espírito pode percorrer as etapas passadas e reconhecê-las como fases de formação, não restando mais novas experiências a serem realizadas, segundo Gadamer. De um certo modo, tudo a ser experimentado já teria sido conhecido. No limite, o próprio conceito de experiência estaria superado. Como afirma Gadamer:

a dialética da consciência deve culminar na superação de toda experiência, que se alcança no saber absoluto, isto é, na identidade absoluta entre sujeito e objeto. A partir daí poderemos compreender por que não faz justiça à nossa consciência hermenêutica a aplicação que Hegel faz à história, na medida em que considera que a história estaria absorvida na auto consciência absoluta da filosofia. 0 saber próprio da experiência é pensado aqui, desde o princípio, a partir de algo no qual a experiência já está superada. (idem, p. 464-5 [361])

Ora, para Gadamer, esse esquema viola a premissa da abertura contida na negatividade da experiência: “A dialética da experiência tem sua própria consumação não em um saber concludente, mas nessa abertura à experiência que é posta em funcionamento pela própria experiência" (idem, p. 465 [362]). Assim, o importante é que a experiência se torne um processo infinito, que nunca encontra termo final, mas apenas o limiar de novas experiências possíveis. 0 ideal gadameriano de negatividade deve ser descrito como uma cadeia de experiências ou como uma série de negações determinadas em sequência sem conclusão, permanecendo sempre de novo em aberto. Em vez de uma "mediação fechada", uma "mediação aberta”, como quer Ricoeur (2010, p. 352) Daí que Gadamer reivindique para a hermenêutica o emprego daquela "má infinitude" que Hegel conjurava (2011, p. 15 [8]). Isso significa que toda experiência feita é potencialmente questionável por uma outra experiência, o que estaria inviabilizado numa filosofia do espírito absoluto. ${ }^{5}$ Quer dizer, todo

5 Por isso, há problemas em descrever o confronto entre Gadamer e Hegel nos termos propostos por Ernildo Stein: "Em Hegel, a dialética quer forçar uma diluição do conceito para dentro da força do 
novo estágio alcançado pela interpretação está sempre sujeito às incertezas que cercam o contato com novos outros.

\section{Dialética negativa}

A interpretação corresponde a uma negação permanente, uma espécie de diálogo infinito em que o intérprete sempre encontra novo recurso para contradizer suas concepções. Ora, isso nos conduz a um outro sentido da negatividade presente na experiência hermenêutica e que também deve certa filiação e ao mesmo tempo um distanciamento com relação a Hegel. Para tanto, cabe perguntar qual o critério dessa autonegação constante. Na hermenêutica, o critério para a checagem dos preconceitos é a própria tradição interpretada, que inclui o intérprete. A precisão dessa tese leva Gadamer a se aproximar de outra ideia de Hegel, a saber, a de que o verdadeiro método da reflexão está no “fazer da própria coisa” (2011, p. 598 [468]), ou, nas palavras, de Hegel (2003, p. 79), no “considerar a coisa como ela é em si e para-si". Nos termos de Gadamer, esse esforço do conceito, de apreensão da coisa, consiste

em não intervir na necessidade imanente do pensamento de modo arbitrário, através de ideias que nos ocorram ou lançando mão desta ou daquela ideia preconcebida. [...] E manter distância de representações "que costumam se interpor", atendose estritamente à consequência do pensamento, faz parte disso. Desde os gregos, chamamos a isso de dialética (Gadamer, 2015, p. 598-9 [468]).

Dialética vem a ser agora o laissez-faire da própria coisa, que exige a não intervenção arbitrária de nossas opiniões prévias a favor da atenção imperturbável ao movimento do que está em questão. Nesse sentido, a apresentação da coisa se torna seu próprio automovimento: “É ela própria que acaba se impondo, na medida em que nos entregamos plenamente à força do pensar e não deixamos valer as ideias e opiniões que pareciam lógicas e naturais” (idem, p. 599 [468]). Por isso, a apresentação “não é mera ação adicional, mas o vir-à-luz da própria coisa, a própria

sentido da palavra que se movimenta no texto escrito. É aí que ele quer espiritualizar as terminações abstratas do pensamento através de um movimento dialético que nunca chega a seu destino" (2014, p. 165). Não fica claro o que se quer dizer quando o sistema hegeliano quer diluir o conceito na palavra que estrutura o texto, tampouco parece ser algo correto. Afinal, seria muito mais condizente lembrar que a filosofia do conceito posta em marcha por Hegel quer engrossar o Conceito através de suas determinações. Se a prosa filosófica se revela como expressão pensada dessa demarche, é porque ela consegue justamente imprimir em seu próprio andamento as determinações do conceito que não se vê diluído nisso, mas solidificado. 0 que dizer então a respeito da ideia de que essa tarefa nunca chega ao seu destino? Isso faria de Hegel um aliado da crítica que Gadamer levanta contra ele: é justamente nisso que o hermeneuta reprova no hegelianismo, o fato de que não deu lugar à abertura da má infinitude do diálogo constante que vem a ser a sobreposição de experiências que justamente nunca alcançam seu destino num saber absoluto enfim liberto da necessidade de novas experiências. Os termos aí propostos prejudicam o rigor conceitual da especificidade que Gadamer, em oposição a Hegel, quer defender para a hermenêutica. 
demonstração filosófica faz parte da coisa" (idem, p. 604 [472]).

Mais uma vez, essa ideia não é exatamente nova no percurso das teses da hermenêutica, pois diz respeito a uma de suas teses clássicas. Já nas conferências sobre Le problème de la conscience historique, Gadamer havia determinado que o critério da reflexão hermenêutica é a mensuratio ad rem (1996, p. 53). O que se tornará central em Verdade e método, onde ele insiste várias vezes: o intérprete precisa "voltar seu olhar para 'as coisas elas mesmas"”, “deixar-se determinar assim pela própria coisa” (2015, p. 355 [271]), para “manter a vista atenta à coisa através de todos os desvios a que se vê constantemente submetido o intérprete em virtude das ideias que lhe ocorrem" (idem, p. 355-6 [271]). ${ }^{6}$ Disciplinada pelo texto, a atenção permanece obstinadamente concentrada nele, resistindo contra a ressonância das preconcepções, o que reitera o valor da abertura:

A tarefa hermenêutica se converte por si mesma num questionamento pautado na coisa em questão, e já se encontra sempre codeterminado por esta. [...] Aquele que quer compreender não pode se entregar de antemão ao arbítrio de suas próprias opiniões prévias, ignorando a opinião do texto da maneira mais obstinada e consequente possível - até que este acabe por não poder ser ignorado e derrube a suposta compreensão. Em princípio, quem quer compreender um texto deve estar disposto a deixar que este the diga alguma coisa (idem, p. 358 [273-4]).

Aqui, a diferença entre objeto e método é solapada. Note-se que isso corresponde ao que vimos a respeito da ideia de história dos efeitos: assim como, segundo essa tese, a própria interpretação se torna um momento do ser da tradição, funcionando como desdobramento de suas possibilidades históricas, também a apresentação da coisa é um momento de seu próprio ser. A interpretação coexecuta o movimento do que está em questão.

0 que interessa acentuar é a negatividade implicada nesse critério. Pois o fazer da própria coisa deve ser garantido "contra a opinião própria” (Gadamer, 2011, p. 76 [61]) do intérprete. O “ouvir imperturbável" exigido nesse processo depende da disposição para

ser negativo contra si mesmo. Quem procura compreender um texto precisa ele

6 Gadamer também recorre a Aristóteles, buscando outra ideia de método não advindo das ciências naturais modernas, para dar conta da peculiaridade da experiência hermenêutica. Para Aristóteles, diz ele, um "método unitário" que pudéssemos escolher "antes mesmo de ter penetrado na coisa" é uma "má abstração". É "o objeto ele próprio que deve determinar o método que permite penetrálo" (Gadamer, 1996, p. 29). Por isso, "[é] preciso perguntar-se se um método que autoriza a se desligar do domínio interrogado (método até certo ponto fecundo no caso da matematização que conhecemos nas ciências da natureza) não conduz, nas ciências humanas, ao desconhecimento [méconnaissance] do modo de ser específico de seu domínio" (idem, ibidem). Ideia semelhante já estava presente quando Gadamer introduziu o conceito de jogo para pensar a experiência hermenêutica da obra de arte. Segundo ele, não se pode dizer que o jogo existe independentemente dos jogadores (como a obra do seu receptor), uma vez que ele só passa a existir ao ser jogado. Desse modo, o jogador é um momento do ser do próprio jogo, que só passa a ser em sua execução (ver Gadamer, 2015 p. 154 [107] ss.). 
também manter algumas coisas à distância, a saber, tudo o que se impõe como expectativa de sentido a partir dos próprios preconceitos, na medida em que isso seja negado pelo próprio sentido do texto [...] É só a autossuspensão da interpretação que leva a termo o fato de que a própria coisa, o sentido do texto, se imponha por si mesmo (Gadamer, 2015, p. 600 [469]).

A insistência de Gadamer é evidente. É preciso ser negativo contra si próprio, negando as próprias opiniões e preconceitos, para que a particularidade da coisa mesma se apresente como tal. Convertida em diálogo infinito, essa autonegação permanente torna-se uma espécie de autoconfusão constante, mas sem a garantia hegeliana da reconciliação final, pois o mau infinito de Gadamer faz com que toda opinião nova adquirida seja sempre virtualmente questionável. Ora, o mais curioso é que Gadamer usará a expressão dialética negativa para descrever esse acento reiterado:

Dialética não é outra coisa do que a arte de conduzir uma conversação e, sobretudo, a arte de descobrir a inadequação das opiniões que dominam uma pessoa, formulando consequentemente perguntas e mais perguntas. A dialética é aqui, portanto, negativa, ela confunde as opiniões. Mas essa confusão significa ao mesmo tempo um esclarecimento, pois libera a visão para olhar adequadamente para a coisa (idem p. 599 [468], grifo do autor).

O uso dessa expressão é provavelmente uma alusão à maneira como Hegel, em seus cursos sobre a história da filosofia, caracterizava pejorativamente a dialética socrática - pelo menos em sua fase "aporética". Pois essa dialética, diria Hegel, ao multiplicar os pontos de vista antitéticos ao infinito, consegue gerar no máximo o resultado de uma “confusão": "é com frequência apenas raciocinante, procedendo a partir de pontos de vista singulares e no mais das vezes apresenta um resultado negativo ou simplesmente nenhum resultado" (apud Arantes, 1996, p. 68). Uma censura que aliás converge com a crítica hegeliana crítica à retórica, também ela em oposição ao elogio gadameriano à arte da produção do discurso convincente. ${ }^{7}$ Ora, é justamente à lógica socrática de pergunta e resposta que Gadamer recorre para desenvolver melhor sua caracterização da experiência negativa. Segundo ele, no movimento da interpretação, a coisa coloca uma pergunta ao intérprete, à qual a negatividade é inerente (2015, p. 482 [375] e 473 [368]), de forma que quando o intérprete falha em compreender a pergunta apoiado em suas opiniões prévias, ele é forçado a pô-las em questão - mesmo movimento do choque que mencionamos. Aquilo que é interrogado é colocado "no aberto", isto é, "deve permanecer em suspenso na esperança da sentença que fixa e decide" (idem, p. 473 [369]). Desse modo,

a negatividade da experiência implica a pergunta. Na verdade, o que nos move a fazer

7 Cf. "Hermenêutica e retórica”, em Gadamer (2011). 
a experiência é o impulso daquilo que não se submete às opiniões preestabelecidas. É por isso que o próprio perguntar consiste mais num sofrer do que num agir. A pergunta se impõe; chega um momento em que não podemos mais fugir dela, nem permanecer afinados à opinião corrente (idem, p. 478 [372]).

Com isso, fica aberta a possibilidade do intérprete assumir um olhar crítico diante das opiniões vigentes em sua situação hermenêutica de partida. A pergunta lançada ao intérprete pela coisa o conduz a questionar a dóxa de seu entorno, uma vez que a opinião difundida “impede a pergunta” (idem, p. 477 [371]). Quem está aferrado às opiniões correntes de seu horizonte bloqueia-se assim à possibilidade de relativizá-las, de ser negativo frente a elas. Em vez disso, “[o]pondo-se à rigidez das opiniões, o perguntar põe em suspenso o assunto com suas possibilidades. Aquele que possui a 'arte' de perguntar sabe defender-se da tendência da opinião comum em reprimir a interrogação” (idem, p. 479 [373]). Por isso, o homem experiente diferencia-se, sobretudo, “daquele que está preso aos dogmas” (idem, p. 472 [368]), já que "conhece os limites de toda previsão e a insegurança de todos os planos" (idem, p. 467 [363]), pois a interpretação levou-o a interrogar ou negar as opiniões comuns que ele partilhava sobre certos assuntos.

Retomando, vemos então que a experiência hermenêutica pode ser descrita como dialética negativa na medida em que se refere à lógica do diálogo, na qual, por meio do automovimento da coisa, o intérprete pode direcionar uma negatividade contra suas opiniões prévias, e assim abrir-se ao que é dito pelo outro. Como na história dos efeitos, esse movimento permitir-lhe tomar parte na própria coisa. Aproximando-o dos diálogos socráticos, Gadamer elogia a negatividade hermenêutica ali onde Hegel a desaprovaria: ela está ligada a uma forma de negação permanente sem uma afirmação final definitiva, depois da qual não haveria mais opiniões a serem confundidas nem necessidade de novas experiências. A experiência hermenêutica não pode ser dialética nesse sentido, mas apenas enquanto dialética negativa. Um permanente diálogo negativo contra si mesmo, como se cada um de nós tivesse dentro de si o seu próprio Sócrates. Daí que possamos dizer que a consciência hermenêutica tem a forma dessa dialética negativa.

\section{Uma outra relação com a tradição}

Vimos até aqui como Gadamer introduz um conceito de experiência negativa que faz jus à historicidade da compreensão e se opõe a uma identificação imediata com a tradição: não raro algo que se acusa no próprio Gadamer. Teríamos o suficiente para concluir que fugimos a essa dificuldade? Ainda não, pois uma outra objeção ainda pode aparecer. Mesmo que quebre aquele acento positivo do movimento da interpretação, a negatividade hermenêutica parece padecer de uma certa unilateralidade da 
tradição com relação ao intérprete: este precisa ser sempre negativo contra si próprio para que a tradição se imponha, o que não deixa de insinuar a atitude de violência contra si exercida em nome da imposição da tradição. Nisto, a tradição fica intocada, pois o intérprete dirigiu a negatividade apenas contra suas preconcepções, mas não contra a tradição. Está aí a base para a acusação de conservadorismo contra Gadamer, que encontra em Habermas o seu melhor representante. Segundo este, "Gadamer é levado pelo conservadorismo daquela primeira geração, pelo impulso de um Burke ainda não varrido diante do racionalismo do século XVIII, à convicção de que a verdadeira autoridade não precisa se comportar autoritariamente" (Habermas, 1971, p. 48). Habermas compara este movimento negativo que descrevemos com o inculcamento desencadeado pela autoridade do professor. Isso estaria presente na maneira como a hermenêutica busca legitimar os preconceitos do intérprete: sob pena das sanções da tradição, ele buscaria desfazer-se de suas concepções para dar lugar às normas da tradição como se isso fosse um ato de livre interpretação, impedindo a transformação da tradição. Daí o juízo de Habermas de que "Gadamer desconhece a força da reflexão que se desenvolve na compreensão” (idem, p. 48): na experiência hermenêutica, a negatividade estaria direcionada unilateralmente contra o intérprete, sem um efeito retroativo sobre a tradição, que ficaria intocada. Como diz Repa, o resultado seria mais um "ensinamento" do que um verdadeiro diálogo (2008, p. 164). A negatividade seria semelhante a um estudante que pune a si mesmo por não entender a mensagem do professor.

É certo, entretanto, que Gadamer desenvolve uma série de argumentos para mostrar que a tradição é transformada pela interpretação, que envolve a modificação de ambos horizontes, o do intérprete e do interpretado. Tendo isso em vista, gostaríamos de mostrar que a consequência da noção de negatividade é justamente mostrar que a experiência hermenêutica não implica uma submissão à tradição. Em linhas gerais, cabe mostrar que, pela experiência negativa, o intérprete aprende a confrontar suas opiniões com as do texto, que é característico do choque, liberando a consciência da distância existente entre suas pretensões e as da tradição. Ou melhor, é ela o que garante que a abertura à tradição apareça como uma escolha disponibilizada a partir da diferença que se abriu. Isso não é só pré-requisito da abertura à tradição: é também abertura para reconhecimento do momento onde a tradição pode ter efeitos indesejáveis sobre o presente e assim ser recusada. Submeter-se sem mais à tradição implica não somente que o intérprete esquece sua própria particularidade, mas que também as pretensões específicas da tradição deixam de ser visíveis. A negação, aqui, deve garantir que o "eu" e o "tu", para empregar termos que Gadamer usa para se referir ao sujeito e ao objeto da interpretação, não se confundam, mas saibam reconhecer suas respectivas pretensões de validade, sem a submissão do outro. Vejamos como Gadamer argumenta nessa 
direção.

O curso da argumentação ainda se insere na seção sobre o conceito de experiência. $O$ ponto de partida está em reconhecer o que está de fato em jogo quando se diz que, no caso da hermenêutica, o que deve vir à experiência é a tradição: é preciso fazê-la “falar por si mesma, como um tu” (Gadamer, 2015, p. 467 [364]). Uma vez que, quando falamos em "tu”, o que vem à experiência assume um caráter de pessoa, essa relação "se torna um fenômeno moral” (idem, p. 468 [364]). Esse ponto já era explicitado por Gadamer em sua concepção de fusão de horizontes. Segundo ele, o horizonte alheio é "um verdadeiro interlocutor, ao qual estamos vinculados como estão o eu e o tu" (idem, p. 468 [364]). É por isso que "[a] consciência histórica sabe da alteridade do outro e do passado em sua alteridade, do mesmo modo que a compreensão do tu sabe do mesmo como pessoa" (idem, p. 470 [366]). A experiência da singularidade do passado é experiência de uma personalidade, uma pessoa única a quem me dirijo e cuja opinião, diferente das minhas, tento compreender. Não à toa, ao descrever o conceito de autoridade que interessa à hermenêutica, Gadamer defende que autoridade é "uma atribuição a pessoas" (idem, p. 371 [285]). 0 que lhe permite, por sua vez, pensar a verdadeira relação com a autoridade da tradição como relação de reconhecimento, pautada na liberdade e no conhecimento. $\mathrm{Na}$ fusão com o horizonte do outro, então “tornamo-nos conscientes da alteridade e até da individualidade irredutível do outro precisamente por nos deslocarmos à sua situação" (idem, p. 403 [310]). A consciência da alteridade depende então de um certo reconhecimento da particularidade do outro, impossível sem o destacamento de nossas próprias opiniões, o que só se pode realizar por aquela negatividade que dirigimos a elas. Este confronto é o que permite que a participação do intérprete na tradição seja mediada por avaliações de suas opiniões e assim seja executada como ato de vontade, uma decisão condicionada pela interpretação das pretensões erguidas diante do intérprete. Ora, note-se que isso tem o efeito reverso, pois, com consciência de sua própria particularidade, o intérprete pode avaliar quando as ideias legadas pela tradição interpretada podem ser também indesejáveis para seu próprio ponto de partida, possibilitando uma recusa refletida das pretensões da tradição. De fato, Gadamer defende que a recusa à obediência à tradição também é um ato de interpretação, já que depende da antecipação dos efeitos indesejáveis dela sobre o presente: “Aquele que se nega a obedecer a uma ordem a compreendeu, e nega-se a fazê-lo porque é ele que a aplica à situação concreta e sabe o que sua obediência implicaria nesse caso" (idem, p. 438 [339]).

Nosso ponto nessa argumentação é mostrar que, para Gadamer, a experiência hermenêutica, mediada pela negatividade, tem um efeito retroativo: se a distância relativa com o "tu" impede o "eu" de violar a singularidade alheia, essa distância implica também que o outro não viole as pretensões singulares do intérprete. Quer 
dizer, a relação reflexiva com o "tu” deve ter implicações mútuas, que podemos pensar como uma exigência intersubjetiva. Ora, sem a negatividade da experiência isso não é possível, pois o conceito positivo de experiência é caracterizado por uma certa universalização abstrata de antecipações bem sucedidas, que é justamente o movimento que permite a um "eu” subsumir o "tu” às suas universalizações prévias. Quando uma experiência negativa, um choque, rompe esse processo, a reflexão permite que ambos os termos guardem uma certa distância entre si. "Na realidade, a pretensão de compreender o outro, antecipando-lhe, cumpre a função de manter a pretensão do outro à distância” (idem, p. 470 [365]). A relação reflexiva com o outro permite, assim, tanto a identificação quanto o distanciamento. Quem deixa de dirigir certa negatividade contra as opiniões recebidas anula a possibilidade desse equilíbrio reflexivo. "Sem essa abertura mútua, tampouco pode existir verdadeiro vínculo humano" (idem, p. 472 [367]). Acompanhamos aqui o comentário de Giegel, que aponta justamente essa reciprocidade:

A partir do esforço de superar na própria conversação a distância que aqui separa os parceiros de diálogo, a autorreflexão hermenêutica cuida para que os parceiros da conversa, por um lado, controlem seus próprios preconceitos e, por outro lado, abramse à reivindicação do outro. Ambos momentos se condicionam reciprocamente: só pode se tornar consciente dos próprios preconceitos quem deixa valer a reivindicação do outro; inversamente, só poderá levar a sério a pretensão de verdade do outro quem está disposto a pôr em jogo seus próprios preconceitos (Giegel, 1971, p. 245-6).

Nesse sentido, a negatividade contra os preconceitos é condição de uma relação mais igualitária entre eu e tu. Ora, a relação conservadora ou autoritária com o outro reflete justamente a supressão dessa relação reflexiva, isto é, se o tu que é a tradição passasse completamente por cima do intérprete (do eu), transpassando sua própria reflexão, ou ainda se o intérprete simplesmente reduzisse a tradição às suas próprias ideias preconcebidas. ${ }^{8}$ Para Gadamer, no entanto, o reconhecimento não se dá de maneira dogmaticamente conservadora - e é justamente contra isso que ele insere o conceito de experiência negativa. Como esta experiência permite esse relativo distanciamento com relação às opiniões, de si e do outro, ela impede qualquer forma de submissão. Como afirma Gadamer:

$8 \mathrm{Na}$ bibliografia de introdução à hermenêutica, é comum encontrar afirmações que sugiram precisamente isso. É o caso de Grondin, por exemplo, que defende que a "fusão é tão bem sucedida, que não se pode mais distinguir o que se destaca do passado nem o que deriva do presente, donde a ideia de 'fusão'" (2006, p. 45). Negru também defende que a fusão de horizontes "anula" a diferença entre o passado e o presente $(2015$, p. 55). Como estamos vendo, não é este o caso. Convém, porém, fazer justiça a Grondin, que em outros textos precisa melhor o teor da fusão de horizontes: "Na integração, a distância não é sempre erradicada: o significado inevitavelmente vem do passado e é compreendido enquanto tal, mas o horizonte do passado está sempre fusionado com o do presente" (2003, p. 59). Ainda no campo de livros introdutórios, o excelente trabalho de Richard Palmer dá notícia dessa nuance: "Gadamer não quer dizer que devemos nos entregar acriticamente à pretensão do texto, negando a do presente; antes, deve ser permitido que a pretensão do texto se mostre como aquilo que é" (1969, p. 189). 
"escutar alguém" não significa simplesmente realizar às cegas o que o outro quer. Agir assim significa ser submisso. A abertura para o outro implica, pois, o reconhecimento de que devo estar disposto a deixar valer em mim algo contra mim, ainda que não haja nenhum outro que o faça valer contra mim (Gadamer, 2015, p. 472 [367]).

Se valer algo em mim contra mim, isto é, se realizar experiências negativas é o medium que permite uma distância mínima entre o intérprete e a tradição, permitindo tanto uma recusa desta quanto uma adesão reflexiva de suas normas, então é preciso reconhecer que uma adesão sem mais à tradição, uma identificação aproblemática, sem a experiência de erros, choques ou estranhamentos, é na verdade apanágio de uma concepção positiva de experiência, contra a qual Gadamer não cansou de opor seu próprio conceito. A relação acrítica com a tradição é uma inimiga comum do próprio Gadamer. Daí que ele tenha lançado mão de um conceito negativo de experiência.

\section{Considerações finais}

Para Gadamer, ser negativo contra as próprias opiniões é a condição necessária para ouvir o outro, enquanto um particular. Todavia, isso não implica submissão, pois entender a particularidade do outro também é o requisito necessário para não aderir a ele cegamente, mas por livre escolha, o que significa também recusá-lo se necessário. Digamos, para recusar algo, é preciso entender o está sendo recusado, e esse entendimento só se realiza quando direcionamos um esforço negativo contra nossas ideias preconcebidas e deixamos o outro falar. Quer dizer, a negatividade da experiência hermenêutica deve operar em mão dupla. Por um lado, quando se defronta com algo novo, o intérprete faz uma experiência e aprende a ter em vista o caráter situado particular de suas ideias, que são chocadas com o outro. Ao tornarse experiente, ele aprende a não submeter o outro a suas opiniões particulares, mas cultiva uma disposição a abrir-se às pretensões individuais apresentadas pela alteridade. No entanto, se a negatividade the permite reconhecer sua própria particularidade, se seu caráter de alguém cultivado [gebildet] permite reconhecer a particularidade e finitude de suas próprias opiniões e das opiniões em geral, então a abertura ao outro que está implicada nisso precisa ser recíproca e garantir também que as pretensões do intérprete não sejam assimiladas pelo outro. Fosse este o caso, a relação com a tradição não se daria mais na forma de experiências. 0 autoritarismo elimina esse componente, uma vez que impede a interpretação. Como diz Gadamer: quando o monarca impõe sua vontade pela força, não resta espaço para "o esforço da interpretação", já não sendo mais possível "hermenêutica alguma” (idem, p. 432 [334-5]). Esta, ao contrário, permite deslocar-se ao horizonte do outro e fundir-se nele, mas também manter a pretensão do outro à distância. Só há experiência com 
o tu onde este não é assimilado ao eu e onde o eu não desaparece no tu. Com a experiência negativa, onde a particularidade é sempre sublinhada, esse risco estaria ao menos por princípio evitado. Quer dizer: se a hermenêutica celebrasse aquele otimismo unilateral com a tradição de onde partimos, não só a própria pretensão particular da tradição não seria mais discernível, como o próprio intérprete e suas particularidades ficariam diluídas na confusão positiva com a tradição. Com a negatividade, trata-se de conservar ambos.

\section{Referências}

Arantes, P. (1996). “Quem pensa abstratamente?”. In: Ressentimento da dialética: dialética e experiência intelectual em Hegel: antigos estudos sobre o $A B C$ da miséria alemã. (pp. 63-173). São Paulo: Paz e Terra.

Araújo, A. M. (2008). A atualidade do acontecer: o projeto dialógico de mediação histórica na hermenêutica filosófica de Hans-Georg Gadamer. São Paulo: Humanitas.

Bilen, 0. (2000). The historicity of understanding and the problem of historical relativism in Gadamer's philosophical hermeneutics. Council for Research in Values and Philosophy.

Di Cesare, D. (2013). Gadamer: a philosophical portrait. Indiana University Press.

Gadamer, H.-G. (1990a). Gesammelte Werke Band 1. Hermeneutik I : Wahrheit und Methode. Tübingen: J. C. B. Mohr.

Gadamer, H.-G. (1990b). Gesammelte Werke Band 2. Hermeneutik 2: Wahrheit und Methode 2. Tübingen: J. C. B. Mohr.

Gadamer, H.-G. (1996). Le problème de la conscience historique. Paris: Seuil.

Gadamer, H.-G. (2011). Verdade e método II: complementos e índice. Tradução de Flávio Paulo Meurer. $6^{a}$ edição. Petrópolis: Vozes.

Gadamer, H. -G. (2015). Verdade e métodol: traços fundamentais de uma hermenêutica filosófica. Trad: Flávio Paulo Meurer. 15ª edição. Petrópolis: Vozes.

Giegel, H. J. (1971). „Reflexion und Emanzipation“. In: Apel, Karl-Otto (org.). Hermeneutik und Ideologiekritik. Frankfurt am Main: Suhrkamp Verlag.

Habermas, J. (1971). „Zu Gadamers Wahrheit und Methode“. In: Apel, Karl-Otto (org.). Hermeneutik und Ideologiekritik. Frankfurt am Main: Suhrkamp Verlag.

Habermas, J. (2014). Conhecimento e interesse. São Paulo: Ed. UNESP.

Hegel, F. (2003). Fenomenologia do espírito. Tradução de Paulo Menezes. Petrópolis: Vozes.

Kant, I. (2016). Crítica da faculdade de julgar. Tradução de Fernando Costa Mattos. Petrópolis: Vozes.

Palmer, R. (1969). Hermeneutics: interpretation theory in Schleiermacher, Dilthey, Heidegger, and Gadamer. Northwestern University Press.

Repa, L. S. (2008). A transformação da filosofia em Jürgen Habermas. São Paulo: Singular. 
Ricoeur, P. (2010). Tempo e narrativa 3: o tempo narrado. Tradução de Márcia Valéria Martinez de Aguiar. São Paulo: Martins Fontes.

Stein, E. (2014). "Hermenêutica e dialética”. In: Rohden, Luiz (org.). Hermenêutica e dialética: entre Gadamer e Platão. São Paulo: Loyola.

Recebido em: 07.10.2019

Aceito em: 06.06.2020

Esta obra está licenciada com uma Licença Creative Commons Atribuição-NãoComercial-Compartilhalgual 4.0 Internacional.

https://creativecommons.org/licenses/by-nc-sa/4.0/

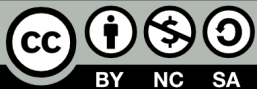

